\title{
Post-Modern Narratives and the Paradigm of Efficiency: participatory democracy on the yellow brick road
}

\author{
As Narrativas Pós-Modernas e o Paradigma da Eficiência: a democracia \\ participativa na trilha dos tijolos amarelos
}

\author{
Cynara Monteiro Mariano ${ }^{1}$ \\ Isabelly Cysne Augusto Maia ${ }^{1,2}$ \\ ${ }^{1}$ Universidade Federal do Ceará, Fortaleza, CE, Brasil \\ ${ }^{2}$ Faculdade Ari de Sá, Fortaleza, CE, Brasil
}

\begin{abstract}
This paper aims to demonstrate how the post-modern narratives contributed to the formulation of distortions in the paradigm of efficiency and democracy. Regarding the methodology, the deductive method was applied, with bibliographic analysis, studying the theoretical context of post-modernity, to understand its consequences. We conclude that democracy must rescue constitutionalism as a basis for legitimacy, removing the demand for efficiency in this role, under consequence of weakening democracy itself. Therefore, the innovation of the text lies in establishing the systematization and correlation between postmodernity, efficiency and deliberative democracy.
\end{abstract}

Keywords: Efficiency. Democracy. PostModernity.
Resumo: $O$ presente trabalho tem o objetivo de demonstrar como as narrativas da pós-modernidade contribuíram para a formulação de distorções no paradigma da eficiência e da democracia. No que concerne à metodologia, aplicou-se o método dedutivo, com análise bibliográfica, estudando-se o contexto teórico da pós-modernidade, a fim de compreender seus desdobramentos. Conclui-se que a democracia deve resgatar o constitucionalismo como base de legitimidade, retirando a eficiência desse papel, sob pena de enfraquecimento da própria democracia. Assim, a inovação do texto está em estabelecer a sistematização e a correlação entre pós-modernidade, eficiência e democracia deliberativa.

Palavras-chave: Eficiência. Democracia. Pós-Modernidade.

Recebido em: 21/08/2019

Revisado em: 06/11/2020

Aprovado em: 17/11/2020 


\section{Introduction}

This paper demonstrates how postmodern narratives, due to the fragmentation of institutional discourses and to the end of metanarratives, contributed to the emergence of other discourse paradigms, such as post-truth and post-democracy, which have changed not only the way we perceive the world, but also the functioning of institutions in a decisive way.

These narratives opened space for the efficiency paradigm to guide the performance of law and politics. The occupation of the law by the economy, through efficiency, was a concern that moved the academic literature during the early years of the 2000s, considering the introduction of the principle of efficiency in the constitutional text through Amendment 19/1998.

With the formal insertion of the principle of efficiency in law, public choices started to be guided by an economic logic of cost versus benefit, rendering a distorted view. In this sense, according to the bibliographic survey carried out, the doctrine's initial concerns with the principle of efficiency reveal a change in the basis of the legitimacy of power, which distanced itself from the text of the constitution and became economic efficiency.

Considering that the basis for the legitimacy of power became a strictly economic view of efficiency, a change in the performance of the institutions was identified, which, currently, has reached the way of acting of democracy. Therefore, this research revealed the existence of a strong communication between the advancement of postmodern narratives and the changes in how democratic institutions function, caused by the efficiency paradigm, as well as the connection between constitutionalism and democracy, considering that, from the moment in which the constitutional text was no longer a basis for the legitimacy of political power, democracy has been affected.

The problem that guided this research was: why did we move away from deliberative democracy? At what point on the path did we take a shortcut that has distanced us from this dimension? 
Based on the findings of this research, one of the countless points that led us to move away from deliberative democracy was the change in the legitimacy basis of political power, which ceased to be the constitutional text and became a distorted view of efficiency. From that point, combined with the narratives arising from postmodernity, the efficiency paradigm advanced and began to occupy other spaces, producing effects on the functioning of democracy.

When pointing out the advance of the efficiency paradigm as one of the forms of rupture with deliberative democracy, we do not mean that such a principle should not be present in the constitutional text, much less that this should not be a legal concern. The point of reflection is the connotation that efficiency has assumed in the face of the philosophical paradigms that have guided postmodernity and how this contributed to the weakening of the constitutional text, after all, there are no public institutions dissociated from the underlying philosophical context.

The contribution made through the present work is establishing the connections between post-modernity, the appearance of efficiency in law, a distorted view of efficiency that has come to occupy other spheres and public institutions. There are relations between this phenomenon and the reduction in the mechanisms of deliberative democracy, showing that constitutionalism and democracy are not points of divergence, but of intense codependence, so one needs the other to maintain its bases.

The deductive method was applied, starting from a broad analysis of the philosophical context, and then verifying more specific elements inserted in this discourse, such as the concept that efficiency has assumed. Bibliographic analysis, focusing on how the doctrine has evolved in the discussion of the principle of efficiency, was also essential for the development of the article.

The work is, therefore, structured as follows: in the first topic, the concepts of postmodernity, post-truth and post-democracy were analyzed, how they relate to each other and how the last two present a common junction in postmodernity. The second topic centered on the paradigm of efficiency and how it trespassed the right to politics, by attacking the bases of democracy, and how this phenomenon is deeply related to the 
context described in the first point of the work. In the third topic, we sought to highlight the effects that such a distorted view of efficiency has had in conducting deliberative democracy, culminating in the answer to the proposed research problem: one of the causes for our departure from deliberative democracy was the distorted view of efficiency assumed even at the beginning 2000s as the basis of political power. Such reflections allowed us to conclude that the resumption of deliberative democracy depends not only on the change of political leaders, but on the way in which institutions operate, which must return to the constitutional text as a foundation. After all, as said, constitutionalism and democracy are not opposing concepts, but complementary.

\section{The Context of Postmodernity, Post-Truth and Post-Democracy}

As well known, in the transition from modernity to postmodernity, several public institutions changed their concepts, articulations and characteristics. In this sense, although there is no agreement on the time frames that marked the transition between these paradigms (if we can speak of transition and not of opposition), the fact is that in modernity some institutions adopted certain concepts that are no longer in line with contemporaneity, as is the case, for example, of the notion of law.

During the period known as modernity, legislation had some characteristics such as autonomy, the link between rights and law and the role of regulating social relationships, which are no longer visible. Nowadays, legislation has become much more diffuse and its link with the State has weakened with the recognition of legal pluralism by several constitutional texts, such as those from Bolivia, Ecuador, among others, that started to consider that the State is not the only source of legal norms.

Such changes in the way of understanding the law reveal that all the institutions must be analyzed from the perspective of a cultural context, since they are social constructions. For that reason, the concepts cannot be understood from a homogeneous, isolated and closed perspective, but as open and plural entities, whose meanings change depending on the set in which they are created and applied (DOUGLAS-SCOTT, 2013, p. 384). 
Therefore, it is necessary to reflect on the paradigms of postmodernity, post-truth and post-democracy, in order to return to some meanings, such as the concept of efficiency, which will allow us to advance in the study of one of the dimensions of democracy, namely: deliberative democracy.

Boaventura de Sousa Santos explains that the instruments of postmodernity enter our societies in a fluid way, without us even realizing it, since our capacities to stop these interventions are diminished by the inexistence of modern resistances to them (SANTOS, 1999, p. 93).

According to the Portuguese author, postmodernity is characterized by being "a myriad of mini-rationalities at the service of a global irrationality". Each sphere of private life starts to be guided by its own rationalities, which contributes to the production of multiple narratives, that, many times, do not dialogue with each other, and produce a discourse that relates, each in its reductionist perspective, to the total irrationality (SANTOS, 1999, p. 102).

The risk in such mini-rationalities is in the production of a discourse that is no longer shared between individuals, which complicates the communication between the most diverse sectarian lines and provides the appearance of the "ideological bubbles", that fail to apprehend reality as a hole, in all its complexity, in addition to being easily manipulated (KAKUTANI, 2018, p. 9).

In view of the fragmentation of discourses, Jean-Marie Guéhenno (1999, p. 13) provides that there is no longer a place for solidarity in the postmodern world, given the wide fragmentation of interests, with individualizing economic disputes.

Due to the pluralism within the postmodern context, the most diverse manifestations are viewed with suspicion, whether they are artistic, legal and other dimensions. As a result of this characteristic, justice, which in the paradigm of modernity focused on the concrete, on what could be objectively calculated, starts, in postmodernism, to approach subjectivism. Then, each situation reveals its own characteristics 
and, therefore, each decision would present its own fundamentals of justice, making reaching consensus a difficult task (CONNOR, 2004).

The concept of postmodernity that we seek to work on in this article is not one that deals with the opposition between this paradigm and modernity, but one that aims at dealing with "celebratory postmodernity", as an adept context of nihilism.

Jean-François Lyotard, when dealing with the concept of postmodernity, adds that this paradigm is characterized by unbelief in meta-narratives, which marks a crisis in metaphysical philosophy and international institutions. Faced with this scenario, the legitimacy of power is based on optimizing performance, efficiency (LYOTARD, 1984, p. 24).

Therefore, postmodernity

[...] could be identified by its heterogeneity, otherness, plurality, indeterminism, discontinuity; its essence denies the belief in reason (which is a demonstration of skepticism)", so "plurality, ambiguity, decentralization, deconstruction, unsystematic thinking, eminently personal analysis predominate: everything is interpretation. (GABARDO, 2009, p. 43-44)

Then, there is a fall in the social importance of the legislator, while the interpreter gains greater relevance.

In this sense, Matei Calinescu (1977, p. 146-147) warns that in postmodernity it is practically impossible to establish a hierarchy of values, due to the plurality of existing narratives, which are often contradictory.

Postmodernity, with its multiple narratives and possibilities, presents as one of its main anxieties the excess of freedom. Bauman (1998, p. 249-250) clearly explains that "[...] being free does not mean not having any beliefs [...]", being free is precisely the potential to be able to believe in several things. Therefore, if the options for choice are unrestricted, then the anguish comes from the responsibility of making a conscious and responsible choice among the various options available. It 
is said that freedom in these terms will hardly lead to happiness. This, if we understand happiness as having no worries.

This extreme fragmentation of reality leads us to a stage of disbelief in utopia and the ability to find solutions. There is no longer any perceived systemic political legitimacy (capable of understanding and absorbing the most diverse social claims, since universal institutions are in crisis), while the market becomes the main space for social integration, which contributes to the exacerbation of individualism. There is no longer a glimpse of a social agent capable of carrying out the necessary prescriptions to overcome social problems, we live in the most absolute discredit of the possibility of overcoming the postmodern narrative by politics (BAUMAN, 2010, p. 260-263).

In view of the absence of a shared reality, it can be said that in addition to postmodernity, we have lived in the era of post-truth. To address this entry into the post-truth era, William Davis rhetorically asks: "How can we still be talking about facts when they no longer provide us with a reality in which we all agree?" (DAVIES, 2016).

In addition to the changes in the notion of truth and the concept of knowledge itself, other institutions were influenced by the postmodernity paradigm, and had to adapt to this new scenario. This was the case of democracy. As we live in a period of oppositions between community and society, homogeneity and heterogeneity, the concept of democracy idealized under the liberal axis has had to seek transformations to survive. The idea is that democracy starts to focus on the multiple epicenters and group alliances, in a real readjustment of the traditional scale of values (DALLMAYR, 1986, p. 144).

In view of this scenario, it is safe to conclude that the marks of reason, scientific truth and democracy itself are not predetermined, but require the promotion of defense mechanisms.

This alliance of postmodernity with the post-truth has led to flexibilities and mischaracterization of democracy itself, through the emergence of the post-democracy paradigm. Post-democracy is present in market societies, in which there is a prevalence of individualism, 
narcissism and a profound approximation between politics and economics, that is, postmodern societies. The State, under this paradigm, no longer enjoys strict limits.

In keeping with this idea of the citizen as a mere consumer of public policies, oblivious to political policies, properly speaking, Céli Regina Jardim Pinto (2017, p. 473-474) adds that post-democracy is marked by forgetfulness of the people. For her, it is necessary that the people recognize themselves as a political subject for the system to work. When they cease to perceive themselves as an antagonistic power and start to be controlled by speeches of authority, such as economic and financial data, democracy loses ground.

There is a perfect alignment between the postmodern logic and the characteristics of post-democracy, such as the notion of citizen-consumer, public efficiency towards market logic, the exacerbation of consumption, the deconstruction of narratives, facilitating the dissemination of false news, among other points.

This does not mean that there is a well-defined chronological line between post-modernity, post-truth and post-democracy, it is only intended to emphasize that post-modernity, due to the changes it has undertaken in social life and in way of knowing and producing knowledge, ended up opening the way for these new paradigms to emerge, since they share common theoretical bases.

Then, it is necessary to point out that overcoming the postmodernity, post-truth and even post-democracy is possible. After all, this state of hopelessness and ending speech is, in itself, a kind of "grand narrative" that seeks to make us believe that the current (dis)order is the only possible one. It turns out that the elements of modernity have not disappeared, they have just been redistributed. Therefore, it is said that the transition from modernity to postmodernity is not an act of continuity, but of a "time against the other", as a kind of "against intellectual revolution" (DIDI-HUBERMAN, 2015, p 75).

Precisely because postmodernity is understood as a paradigm that opposes modernity, due to the repositioning that makes its elements, 
it is understood that it is possible to carry out a modern critique of such a model, even though we are inserted in a postmodern mindset (GABARDO, 2009, p. 43). Likewise, it is incorrect to say that this process of relativizing the facts is an end point, even though it is a process that will not allow setbacks. Therefore, those discouraged by this incorrect turn must rise and counterattack.

Under the belief that the context briefly analyzed in the present topic is capable of being overcome, we resume the discussions on deliberative democracy and constitutional prescriptions.

Such analyzes are extremely important for the rule of law to reconstruct one of its main pillars: legality, which has been deeply attacked by other narratives, such as those of an economic nature, mainly because of what the post-truth prescribes.

Thus, the confrontation between the postmodern narrative of efficiency and what the constitutional text prescribes, as well as the complications of this in the weakening of participatory democracy, will start to work on the subsequent topic.

\section{The Efficiency Paradigm: from attacks on the law to attacks on democracy}

In the face of postmodernity, constitutionalism takes on new shapes. Legality loses space to effectiveness and results. Still in 2001, Luís Roberto Barroso clarifies that, under the post-modernity paradigm, public law becomes a central concern of governance (BARROSO, 2001, p. 13).

The government's legitimacy coincides with the efficiency of its action. In that sense, “[...] it doesn't matter that politicians represent the people or have high ideals. The elections depend on a performance, be it previous, on television, or poster, on the efficiency of the administration" (GABARDO, 2012, p. 334).

Therefore, there is a disbelief in politics, while from the Public Administration is demanded an efficiency with the logic of private 
initiative about quantitative results, after all, the more, the better and more efficient. Efficiency with state and public logic is placed in background.

From a legal perspective, administrative efficiency must seek to achieve a solution that meets the public purpose. Then, efficiency is not only focused on economic aspects, but also on undertaking the development of all state functions, aiming at human development and at the happiness of individuals (CAPILONGO, 2017, p. 10-13).

In this sense, administrative efficiency must be understood from a systematic perspective, in line with the entire constitutional text, so that it remains evident that this principle has a complex legal content, going beyond merely economic aspects. As stated by Daniel Hachem and Emerson Gabardo (2018, p. 137-138), the legal content of the principle of efficiency has some dimensions: 1) exercise administrative activity with the maximum speed, readiness, money savings and productivity as possible; 2) seek the realization of the public purpose, underlying the constitutional norms; 3) seek the most appropriate means for the realization of the public interest; 4) give maximum effectiveness to legal commands, positively established; and 5) always act in accordance with fundamental rights and with other principles and rules that guide administrative activity.

It is observed that the principle of efficiency must be attached to the provisions of the constitutional text. It does not mean a relaxation of the text. On the contrary, it is a mechanism that was devised to give concrete effect to the rule by choosing the most appropriate, fastest, most productive and most economical means. In this sense, the principle of efficiency should act as a mechanism for strengthening the constitution, through its practical perspective on results.

Due to the inefficient performance of the State, whose actions distanced themselves from the constitutional text, allied with the narratives of post-modernity and all the other consequences of it, the principle of efficiency started to dangerously approach the economy, creating the mistaken view that the Public Power would be inefficient, while the private initiative, through society, would be able to produce better results. There is a true dichotomy between State and society. 
It can be seen that with postmodernity there are changes in the way of understanding Law, since with the crisis of narratives that are intended to be universal, the basis for the legitimacy of power ceases to be the text and becomes the emergence of a new model, concerned with financial management. As Goyard-Fabre (1999, p. 298) warns, "[...] the crisis of modern political legitimacy come from the fact that reason self-destructs by sacrificing its universality". Therefore, there is a clear gap between what the principle of efficiency should be and what it has become.

In this sense, the basis for the legitimacy of political power becomes efficiency, in the way of result management, maximization of utilities, then the economy overshadows the law. This leads to an "economy of the law" or "money dictatorship", in detriment of democratic choices and priorities developed in the constitutional text and in the legislations elaborated by the Legislative Power (GALDINO, 2005, p. 244-249).

In the context described, the basis for the legitimacy of political power is no longer the constitutional text and becomes the logic of market efficiency: the more efficient a government is, the more legitimate it will be, even if this imposes irreparable sacrifices to the constitutional text and to the separation of powers, with the preponderance of the Executive Power over the Legislative Power. This causes severe damage to the tripod of the democratic State under the rule of law, which is composed of: Democracy, Law and Legitimacy.

If public choices start to be carried out focusing on a distorted paradigm of efficiency, constitutional values and principles are placed on the background, there is a preponderance of pragmatism and economics, reflecting only the interests of who is leading the choice process, and not those of the community. Therefore, centralizing and non-participatory processes are prioritized. After all, the faster the choices are made, the more efficient the management will be and the more legitimate the government will be, as it will be able to carry out its political promises, even though it costs a loss of strength and importance of democracy (GABARDO, 2003, p. 100-101).

In this sense, when an eminently economic view of the principle of efficiency and not constitutional values becomes the guiding thread 
of public choices, participatory democracy is far from being realized. After all, the citizen is seen and treated as a mere client, consumer of public policies and, as every client does not participate directly in the deliberative processes, under this scenario there is a reduction "[...] of all the wealth of human facets to its simple economic dimension of consumption" (MARTINS, 2000, p. 113).

Marcelo Andrade Cattoni de Oliveira (2012, p. 68 and 251) affirms that, in the Democratic State of Law, the concept of citizen-client should be abandoned, so that rights could become effective through the dimension of citizen-participant in the deliberative processes, in a way that public service users are not understood only as consumers, but as true participants in the definition of state priorities. Despite being formally inserted in a Democratic State of Law, our social context of postmodernity, post-truth and post-democracy has distanced us from the effective achievement of this legal model of citizen-participant.

The perspective of the citizen-client, as that citizen who does not participate in the decision-making processes of Public Administration, aligns with the context of postmodernity, in which efficiency (and not the constitutional values) guides the public choices, as in a marketing logic. Only the results are enough, and there is a strong Executive to guarantee efficiency and to resolve eventual crises of legitimacy (MAIA, 2009, p. 56). After all, how to criticize an efficient government?

It should be noted that the major problem in the conception of the citizen as a client/consumer of the public service is that, despite the fact that the client is targeted, he does not participate in the formulation of the guidelines of the services provided. Thus, this distancing from the sphere of administrative decision produces not only a mitigation in the concept of citizenship, insofar as it removes from the citizen the ability to be the subject of decisions and influence the destinies of society (NOHARA, 2012, p. 119), but it also distances the possibility of achieving a critical and deliberative democracy. Eran Vigoda (2002) affirms that the great concern in treating the citizen as a client is to promote unilateral management, with passive and alienated citizens from public choices. 
It is clear, therefore, that the ideology of the citizen-client, although seductive when incorporating the logic of the efficiency of the private initiative, actually contributes to the objectification of the citizen, since it weakens the perception of the Administration as a res publica, which must be managed by all members of the community for the realization of their interests (BUCCI, 2002), in compliance with the constitutional dimension of the public interest.

It is remarkable that all elements of the present work are deeply connected. Postmodern narratives have led to the production of a distorted efficiency paradigm, in which the constitutional text has been relaxed and the country's economic status has been the basis for giving legitimacy to power (if the economy is doing well, power achieves stability).

The adoption of efficiency, from a purely economic perspective, as a guiding criterion for public choices, harms not only the universalizing narrative of Law, since each case will be decided under the strictly financial aspect; it also leads to the production of a citizen-customer, who is distanced from the spaces of political deliberation, even allowing the constitutional apparatus of democratic participation to be more flexible, centralizing decisions in the figure of the manager.

A citizen distanced from administration and political choices has his citizenship levels mitigated and the very notion of people, as a subject confronting the established order, ceases to exist, since technical and economic reports are assumed to be indisputable truths, which leads to a clear exchange of law for the economy.

Regarding this situation, Emerson Gabardo warns that the mistaken view of the principle of efficiency has led to a state of nihilism in the separation of powers, once for the prestige of efficiency under the economic sphere, invariably becomes the rule, through the performance of subjective interpretations (GABARDO, 2016, p. 214).

The literature review carried out in this article shows that until early 2000s, the concern of the doctrine was about the invasion of the economy in the legal sphere, as through the adoption of the efficiency paradigm as a foundation for the legitimacy of political power, there was 
a loss of normative force in the constitutional text. Currently, in a global perspective, some question the feasibility of maintaining the democratic regime, given the occupation of political space by the efficiency paradigm.

With that, it can be said that the first attacks of postmodern narratives were to the rule of law. Currently, the most intense attacks are on the pillar of Democracy. After all, if there are no choices to be made, there is no reason to establish collective discussions.

The analyzes of the present topic aimed, in conclusion, to establish an overview of the influence that a distorted view of the principle of efficiency has produced in the process of public choice, which has obstructed the construction of a citizen that effectively participates in the spaces of administrative deliberation.

Finally, we should discuss the position of deliberative democracy in this context of postmodernity, post-truth and post-democracy. Are there still alternatives to achieve it?

\section{Deliberative Democracy at the end of the Road: are there still ways to achieve it?}

In the described context, deliberative democracy is at the end of the road, in which great and innumerable challenges will have to be overcome until we manage to reach it, coupled with an intense care and attention of not straying apparently more advantageous trails.

Waldron, despite being a critic of deliberative democracy, recognizes the need for a reasonable dissent for the maintenance of democracy. The author explains that "[...] we must find a way to choose a single policy, in which we can participate despite our disagreement on the merits". The point is that individuals can be openly heard, even if they disagree about the process chosen to carry out this hearing (WALDRON, 2003, p. 192). Then, dissent is an essential point for maintaining democracy. 
Habermas' position is similar, when developing the theory of communicative action, according to which public deliberation would be the source of legitimation of power, so that the deliberations should prevail over voluntary decisions (HABERMAS, 1989). Public deliberation is not a matter of mere dialogue, but of true argument as a means to achieve consensual understanding.

In face of the crisis of law, we cannot change it through metalegal considerations, such as morals and economics, but by law itself (only law creates and transforms law). Therefore, as argumentation and communication are part of the fabric of law, deliberative democracy, due to the communicative action it provides, constitutes one of the main means of updating the law itself (GOYARD-FABRE, 2003, p. 325).

From this perspective, deliberative democracy is not just a product to feed the vanity of some, but it constitutes an indispensable dimension of democracy and an essential instrument for updating the law through proper legal instruments.

The theoretical framework followed in this work is in line with the perspective of Chantal Mouffe, for whom dissent in a democracy is essential, since "[...] radical democracy requires that we recognize the difference - the particular, the multiple, the heterogeneous -, everything that, in reality, has been excluded by the abstract concept of man" (MOUFFE, 1996, p. 26). From the same perspective, we should observe the ideas of Marcelo Neves, for whom the deliberation process developed by Habermas' communicative action is a procedure for intermediating dissent, "not for its amortization or avoidance" (NEVES, 2001, p. 132). Precisely understanding that the manifestation of dissent is a basic element of democracy, we can understand that the resumption of instruments that make deliberative democracy viable is crucial for the continuity of the democratic regime. After all, it is in public discussions that dissent remains evident and that consensus procedures can be constructed, reinforcing the legitimacy of political power, since administrative deliberations would be taken in line with social interests and priorities. 
As Luis Manuel Fonseca Pires (2014, p. 496) warns, it is the mission of the public authority to act as an interpreter, as a kind of mediator between cultural differences, diversities of customs and traditions aiming to reach the public interest. To achieve this goal, it is necessary to reinforce the instruments of deliberative democracy, which also contributes in fighting against corruption, because when inserting popular participation in administrative decision-making, the tendency is the expansion of social control and a consequent greater transparency in the making of public choices (PIRES, 2014, p. 499).

Deliberative democracy as an instrument for handling dissent seems indispensable, therefore, for good public choices. As Caroline Muller Bittencourt and Janriê Reck affirm, these "[...] difficult choices cannot be delegated to a unilateral, solipsist vision, but built communicatively, based on the debate and the participation of various actors" (BITENCOURT; RECK, 2018, p. 64).

Everything that has been worked on so far in this topic reveals the importance of deliberative democracy for public choices and for the continuity of democracy, because it is through this dimension that the dissent remains evident, enabling a true critical democracy in which choices are not definitive and immutable, but possibilities, subject to constant discussion (ZAGREBELSKY, 2011, p. 135).

Thus, the question that motivates the present production is: Why did we get lost on the road that leads to deliberative democracy and why we have not managed to reach this dimension?

As explained in the previous topic, one of the causes of this deviation in the democracy road is the phenomenon of occupation of law and politics by the efficiency paradigm, which was possible because of the narratives arising from postmodernity, in which the public discussions have not only been left out, but a process of destruction of the legal instruments that make deliberative democracy viable has also started. To exemplify, we should point the recent decree issued by the Federal Executive that intended to end more than 30 (thirty) councils of civil 
participation, under the justification of cost reduction ${ }^{1}$, an argument that undoubtedly finds substrate in the logic of market efficiency, in clear elucidation of the notorious "cost $\mathrm{x}$ benefit" reasoning.

This substitution of legitimacy of the political power pointed in the constitutional text for efficiency stemmed from the most diverse difficulties encountered in implementing the constitution. In this sense, Robert Dahl states that "[...] economic difficulties, particularly when they take the form of severe unemployment or accelerated inflation, generate demands for a hegemonic regime and a centrally controlled social order" (DAHL, 2005, p. 89).

Thus, under the argument that things will improve if certain guarantees are left aside in favor of increasing levels of market efficiency, people start to accept institutional disruptions. After all, everything will pass soon and there is no choice but to accept the bitter remedy of losing the instruments of deliberative democracy and the right to dissent itself. All of this produces the notion that "[...] it remains only the fleshless power that things are like this, and those who do not accept them to take to the streets, where the police are waiting for them. This is the legitimacy crisis" (CASTELLS, 2018, p. 11).

The idea that it is up to the community to agree with the deliberations taken by technicians, who supposedly know how to define better than the people, which are the best measures to be taken, indicate that the usurpation of public deliberation spaces by efficiency leads to technocracy and silencing people, producing a "democracy" only in formal aspects, since, in practice, its characteristics are far from being implemented.

After all, by demonstrating itself as an immanent truth, existing in the external environment and that should only be deciphered by technicians and specialists, people tend to simply accept and not debate what is proposed in terms of public policies, so the paradigm of efficiency undoubtedly drives us away deliberative democracy; referring to the ideas that Plato, even at the beginning of the democracy of the Greek, presented as the basis for the legitimation of democracy. As exposed by Ian Shapiro

${ }^{1}$ See news published in El País (2019). 
in his book The Moral Foundations of Politics, the legitimacy of a form of government would be linked to its effectiveness in making "the world safe for philosophy", in which the search for truth would be merely contemplative, to be developed only by those who have the appropriate intellectual ability (SHAPIRO, 2006, p. 257-258).

Added to the return of technicality, we have the deficit in strategic capacity that has marked the performance of Public Administration. At the same time that political decisions are surrounded by technical and non-deliberative grounds, it is also noted that administrators have been working only with the perspective of the present, transferring controversial and difficult decisions to future generations, characterizing us as the generation of immediacy (INNERATY, 2017, p. 268).

Therefore, the paradigm of efficiency completely changes the bases of the democratic regime, contributing to make democracy a regime of technicians, in which people are silenced, social dissent is ignored, and decisions are taken to solve only immediate issues.

The considerations traced throughout the work reveal a quick panorama of how we move away from the democracy road, indicating, also, the urgent need to return to the right one, so that the democratic regime is practiced with all its characteristics. With this, a second question emerges: how to return to the democratic path, avoiding the fallacies of the efficiency discourse?

On this question, some initial considerations can be made (since this is not at the heart of the discussion of the present work), and a possible answer we can mention is the need for change in the way of understanding institutional procedures. Personnel replacement is not enough if the institutions continue to be misunderstood, as Daniel Innerarity warns: "[...] the movement of people does not guarantee any novelty when the practices are maintained" (INNERARITY, 2017, p. 270).

Thus, we need innovations in a way that institutions understand and act, with the production of an intelligent political system, which is undoubtedly more appropriate than the "government of the best". After all, one of the main objectives modernly is to establish a mechanism for 
reflection in political life, minimizing decision-making practices driven by immediacy.

From the above, it appears that the strengthening of deliberative democracy goes through an attitude of rethinking the functioning of the institutions themselves, and not only through modifying individuals. There is also a need for cultural change, in which the immediate decisionmaking processes are supplanted by collective spaces for reflection and maturation. After all, it cannot be expected that democratic efficiency will produce results with the same agility as private initiative; to intend such an equalization, as it has been abundantly worked on throughout this work, constitutes a risk for democracy itself.

It is said that the return of political life for the promotion of institutions that allow the exercise of deliberative democracy is conditioned to the understanding that constitutionalism and democracy are complementary. From the moment that the constitutional text is flexible about efficient speech, democracy also loses its vigor. After all, it is constitutionalism that imposes limits on the will of the majority, when it is intended to adopt measures that culminate in the restriction or flexibility of fundamental rights (GABARDO, 2017, p. 84). At the same time, it is deliberative democracy that allows for intense social participation in public choice, enabling an approximation with the constitutional text.

In summary, there are ways to return to deliberative democracy, but this should go through the resumption of the preponderance of the constitutional text, which will need to be followed by readjustments in the way institutions operate, indicating that we still have a long road to go through.

\section{Conclusion}

The present work allowed us to conclude that the context of post-modernity, combined with the narratives that resulted from such a paradigm, such as post-truth and post-democracy, caused a distortion in the concept of efficiency. 
With the insertion of the principle of efficiency in the constitutional text, public choices began to be made through a distorted and eminently economic view, and caused a change in the legitimacy basis of political power (which ceased to be the constitutional text and became efficiency itself).

Thus, such practices culminated in a more flexible application of the constitution and a weakening of the institutions themselves, which started to act driven by an economic logic. And so, the efficiency paradigm gained more and more space in the political area and started to impact one of the main dimensions of democracy: deliberative democracy. After all, it is not efficient, agile and economical to listen to dissent; it is best to build the discourse of some supposed universal consensus.

Constitutionalism was, in this scenario, seen as an obstacle to economic development. With that, people thought that constitutionalism and democracy would be opposite concepts, because if the majority chose a government official who lays the foundations of his legitimacy on efficiency, the majority of the population would not be prioritizing the constitutional text, but rather the practical results, regardless of the costs that this may entail.

It turns out that democracy and constitutionalism are complementary and cannot go in a dissociated way. As we have seen, making the constitution more flexible has effects on democracy, especially in its deliberative dimension.

Furthermore, deliberative democracy is not a dimension of the political regime that can be more flexible, in fact it is essential and underlies the very continuity of democracy. The identified answer to the proposed research problem is that the advance of the efficiency paradigm (with the distortions caused by postmodern narratives) was one of the many forces that took us off the path of deliberative democracy. It is now up to us to face the challenges of the path before us; restructuring the institutions, rebuilding the strength of the constitutional text and developing the citizen awareness that deliberative democracy is an indispensable dimension of democracy - and that for its development and 
improvement, the participation of individuals, with the identification of existing dissent, is necessary.

Given the limitations of the work, discussions on how to make the efficiency paradigm recede or how to reshape institutions, creating an intelligent democracy, have not been deepened. The objective was to show that there is no democracy without constitutionalism and that deliberative democracy cannot be made more flexible under the risk of the democratic system's characterization being lost. In addition, we sought to demonstrate that, as they emerged, the paradigms of postmodernity, post-truth and post-democracy may retreat; for this, however, it becomes essential to formulate a citizen consciousness and that it is up to each one of us, especially academics, denouncing the attacks on the Constitution and on its founding ideology.

\section{References}

BARROSO, Luís Roberto. Fundamentos teóricos e filosóficos do novo direito constitucional brasileiro: Pós Modernidade, Teoria Crítica e PósPositivismo. Revista Emerj, Rio de Janeiro, v. 4, n. 15, p. 11-47, 2001. BAUMAN, Zygmunt. Legisladores e Intérpretes: sobre modernidade, pós-modernidade e intelectuais. Rio de Janeiro: Zahar, 2010.

BAUMAN, Zygmunt. O Mal-Estar da Pós-Modernidade. Rio de Janeiro: Zahar, 1998.

BITENCOURT, Caroline Müller; RECK, Janriê Rodrigues. Formulação e execução de políticas sociais no cenário brasileiro a partir de uma ação comunicativa: Atores sociais. In: BITENCOURT, Caroline Müller; RECK, Janriê Rodrigues. Abordagens Epistemológicas sobre Democracia, Políticas Públicas e Controle Social. Santa Cruz do Sul: Essere Nel Mondo, 2018. p. 64-83.

BUCCI, Maria Paula Dallari. Direito Administrativo e políticas públicas. São Paulo: Saraiva, 2002. 
CALINESCU, Matei. Faces of Modernity: Avant-Garde, Decadence, Kitsch, Bloomignton: Indiana University Press, 1977.

CAPILONGO, Celso Fernandes; GONZAGA, Álvaro de Azevedo; FREIRE, André Luiz. Enciclopédia Jurídica da PUCSP, tomo II: direito administrativo e constitucional. Coord. Vidal Serrano Nunes Jr. [et al.]. São Paulo: Pontifícia Universidade Católica de São Paulo, 2017. CASTELLS, Manuel. Ruptura: a crise da democracia liberal. Rio de Janeiro: Zahar, 2018.

CONNOR, Steven. Postmodernism. Cambridge: Cambridge University Press, 2004.

DAHL, Robert A. Poliarquia: Participação e Oposição. São Paulo: Editora da Universidade de São Paulo, 2005.

DALLMAYR, Fred R. Democracy and Post-Modernism. Huma, Netherlands, v. 10, p. 143-170, 1986.

DAVIES, William. The Age of Post-Truth Politics. 2016. Available at: https:/www.nytimes.com/2016/08/24/opinion/campaign-stops/the-ageof-post-truth-politics.html. Accessed on: June 9th, 2019.

DIDI-HUBERMAN, Georges [et al.] A república por vir: arte, política e pensamento para o século XXI. 2. ed. Lisboa: Fundação Calouste Gulbenkian, 2015.

DOUGLAS-SCOTT, Sionaidh. Law after Modernity. Oregon: Hart Publishing, 2013.

EL PAÍS. Conselhos sociais sobre indígenas, LGBTs e população de rua estão na mira de Bolsonaro. [2019]. Available at: https://brasil. elpais.com/brasil/2019/04/15/politica/1555364075_912856.html. Acessed on: June 16th, 2019.

GABARDO, Emerson. A flexibilização da legalidade mediante o prestígio de uma ideia equivocada de eficiência e uma visão niilista da separação dos poderes. In: HACHEM, Daniel Wunder; GABARDO, Emerson; SALGADO, Eneida Desiree. Direito Administrativo e suas transformações atuais: homenagem ao professor Romeu Felipe Bacellar 
Filho. Curitiba: Íthala, 2016. (Anais do Seminário da Faculdade de Direito da Universidade Federal do Paraná). p. 207-217.

GABARDO, Emerson. Eficiência e Legitimidade do Estado: uma análise das estruturas simbólicas do Direito Político. São Paulo: Manole, 2003.

GABARDO, Emerson. A eficiência no desenvolvimento do Estado brasileiro: uma questão política e administrativa: Legalidade, Segurança Jurídica, Impessoalidade, Publicidade, Motivação, Eficiência, Moralidade, Razoabilidade, Interesse Público. In: MARRARA, Thiago. (org.). Princípios de direito administrativo. São Paulo: Atlas, 2012, p. 327-351, p. 334.

GABARDO, Emerson. O jardim e a praça para além do bem e do mal: uma antítese ao critério de subsidiariedade como determinante dos fins do Estado social. 2009. 409f. Tese (Doutorado) - Curso de Ciências Jurídicas, Universidade Federal do Paraná, Curitiba, 2009.

GABARDO, Emerson. Os perigos do moralismo político e a necessidade de defesa do direito posto na Constituição da República de 1988. A\&C Revista de Direito Administrativo \& Constitucional, [s.l.], v. 17, n. 70, p. 65-91, 1 dez. 2017. DOI: http://dx.doi.org/10.21056/aec.v17i70.847.

GALDINO, Flávio. Introdução à teoria dos custos dos direitos: direitos não nascem em árvores. Rio de Janeiro: Renovar, 2005.

GÉHENNO, Jean-Marie. O fim da democracia: um ensaio profundo e visionário sobre o próximo milênio. Tradução de Howard Maurice Johnson e Amaury Temporal. 2. ed. Rio de Janeiro: Bertrand Brasil, 1999.

GOYARD-FABRE, Simone. Os princípios filosóficos do Direito Político moderno. São Paulo: Martins Fontes, 1999.

GOYARD-FABRE, Simone. O que é democracia? São Paulo: Martins Fontes, 2003.

HABERMAS, Jurgen. La souveiranaté comme procedure: um concept normatil del espace public. Paris: Lignes, 1989. n. VIII. 
HACHEM, Daniel Wunder; GABARDO, Emerson. El principio constitucional de eficiencia administrativa: contenido normativo y consecuencias jurídicas de su violación. Revista Mexicana de Derecho Constitucional, Cidade do México, v. 39, p. 131-167, 2018.

INNERARITY, Daniel. A política em tempos de indignação: a frustação popular e os riscos para a democracia. Rio de Janeiro: LeYa, 2017.

KAKUTANI, Michiko. A morte da Verdade: notas sobre mentira na era Trump. Intrínseca: Rio de Janeiro, 2018.

LYOTARD, Jean-François. The Postmodern condition: a report on knowledge. Theory and history of literature. United Kingdom: Manchester University Press, 1984. p. XXIV.

MAIA, Taciana Mara Corrêa. Por uma Administração Púbica

Democrática: além da administração pública gerencial, a administração pública societal. 2009. 116f. Dissertação (Mestrado) - Curso de Direito, PUC MG, Belo Horizonte, 2009.

MARTINS, Marcos Francisco. Uma "catarsis" no conceito de cidadania: do cidadão cliente à cidadania com valor ético-político. Campinas-SP, Puc-Campinas: Revista de Ética, [s.l.], 2000.

MOUFFE, Chantal. O regresso do político. Lisboa: Gradiva, 1996.

NEVES, Marcelo. Do consenso ao dissenso: o Estado democrático de direito a partir e além de Habermas. In: SOUZA, Jessé (org.). Democracia hoje: novos desafios para a teoria democrática contemporânea. Brasília: Editora Universidade de Brasília, 2001. p. 111163.

NOHARA, Irene Patrícia. Reforma Administrativa na Década de 90 e Modelo Gerencial. In: NOHARA, Irene Patrícia. Reforma Administrativa e Burocracia: impacto da eficiência na Configuração do Direito Administrativo Brasileiro. São Paulo: Atlas, 2012. Chapter 3. p. 77-144.

OLIVEIRA, Marcelo Andrade Cattoni de. Teoria da Constituição. Belo Horizonte: Initia Via, 2012. 
PINTO, Céli Regina Jardim. Tempos de pós-democracia: ausência do povo. Revista Tempo e Argumento, Florianópolis, v. 9, p. 472-481, 2017.

PIRES, Luis Manuel Fonseca. A discricionariedade administrativa e o interesse público líquido. In: MELLO, Celso Antônio Bandeira de; ROCHA, Sílvio Luis Ferreira; SAAD, Amauri Feres. Direito Administrativo e Liberdade: estudos em homenagem a Lúcia Valle Figueiredo. São Paulo: Malheiros, 2014. p. 486-500.

SANTOS, Boaventura de Sousa. Pela mão de Alice: o Social e o Político na Pós-Modernidade. Porto: Edições Afrontamento, 1999.

SHAPIRO, Ian. Os fundamentos morais da política. São Paulo: Martins Fontes, 2006.

VIGODA, Eran. From responsiveness to collaboration: Governance, citizens, and the next generation of public administration. Public Administration Review, [s.l.], 2002.

WALDRON, Jeremy. A Dignidade da Legislação. Tradução de Luís Carlos Borges. São Paulo: Martins Fontes, 2003.

ZAGREBELSKY, Gustavo. A crucificação e a Democracia. São Paulo: Editora Saraiva, 2011.

Cynara Monteiro Mariano is post-doctorate from the University of Coimbra. $\mathrm{PhD}$ in Constitutional Law from the University of Fortaleza. Master in Public Law (Constitutional Legal Order) from the Federal University of Ceará. ViceCoordinator of the Postgraduate Program in Law at the Federal University of Ceará.

E-mail: cynaramariano@gmail.com

Professional address: Universidade Federal do Ceará, Faculdade de Direito. Rua Meton de Alencar, s/n - até 1.269/1.270, Centro, Fortaleza, CE. CEP: 60035-160. ORCID: https://orcid.org/0000-0001-6157-8779 
Isabelly Cysne Augusto Maia is $\mathrm{PhD}$ student and Master by the Postgraduate Program in Law at the Federal University of Ceará. Specialist in Administrative Law from PUC-MG. Professor at Faculdade Ari de Sá. Lawyer.

E-mail: isabellycysne@gmail.com

Professional address: Faculdade Ari de Sá. Av. Heráclito Graça, n. 826, Centro, Fortaleza, CE. CEP: 60140-060.

ORCID: https://orcid.org/0000-0002-7178-336X 